\title{
PROBLEMY ROZWOJU PORTU SZCZECIN-ŚWINOUJŚCIE (NA KANWIE 90. URODZIN PROF. ZW. DR HAB. FRANCISZKA GRONOWSKIEGO)
}

\author{
Bogusław Trzciński \\ Bulk Cargo - Port Szczecin sp. z o.o.

\section{Leon Dorozik} \\ Wydział Nauk Ekonomicznych i Zarządzania, Uniwersytet Szczeciński
}

Czas płynie szybko, a życie jeszcze szybciej, więc starajmy się wszystko co możliwe zrobić dzisiaj i nie odkładajmy tego na później, bo może się okazać, że tego „później” nie będzie. To stwierdzenie odnosi się do wszystkich płaszczyzn naszego postępowania. Pamiętamy, jak to było 50 lat temu, kiedy zaczynaliśmy studiować i nie potrafiliśmy poruszać się po budynku na Mickiewicza. Pamiętamy jednak jak szybko się uczyliśmy. Nie wiadomo kiedy przyszedł czas wyboru kierunków studiów, seminariów, końca studiów i później pracy. Te momenty celowo podkreślamy, bo były to skrzyżowania w naszym życiu. Ich pokonanie rzutowało na wszystko co potem następowało. Transport morski, elitarny kierunek tworzony wówczas przez doc. dr hab. Franciszka Gronowskiego i doc. dr Bolesława Koselnika w Szczecinie, który wówczas przyrównywano tylko do handlu zagranicznego na SGH i transportu morskiego w Sopocie oraz informatyka, która zaczynała raczkować na świecie, a budowana u nas na Wydziale przez doc. dr hab. Tadausza Wierzbickiego - to były wówczas topowe kierunki do studiowania.

Nie mieliśmy kompleksów, zresztą zawsze nam powtarzano, „nie miejcie kompleksów miejcie marzenia”. Marzenia mają to do siebie, że jak się bardzo chce i pragnie, to się spełniają. Szczególnie wówczas, gdy poparte są ciężką i wytężoną pracą, dlatego szliśmy do przodu, bez oglądania się za siebie i nie bacząc na nikogo staraliśmy się znajdować swoją własną drogę i budować przyszłość .

Podczas tego „marszu do przodu”, który tak naprawdę nazywa się życiem (pokonywaniem życia), warto od czasu do czasu zatrzymać się, odsapnąć i zastanowić - czy warto było i czy kierunek, a szczególnie osiągnięty cel - wart był tego wysiłku i zaangażowania?

$\mathrm{Z}$ naszego punktu widzenia możemy stwierdzić, że błądziliśmy nie za dużo. A do ograniczenia błądzenia, przyczyniło się w znacznym stopniu też to, co wynieśliśmy z naszej uczelni, wydziału, naszych seminariów i niekończących się dyskusji na seminariach z naszymi promotorami. Bo wzorcem dla nas byli nasi mistrzowie, promotorzy, którzy nigdy nie skąpili nam 
rad i podpowiedzi. To wszystko razem było dla nas zaczynem do działania i podejmowania się różnych, często karkołomnych, aby nie powiedzieć zwariowanych pomysłów. Zawsze jednak w uszach mieliśmy podpowiedz „dobrego duszka” - miejcie marzenia.

Dla wielu takim marzeniem była praca w porcie czy żegludze morskiej. Tam wylądowało wielu z nas 45 lat temu i tam przepracowaliśmy większość naszego życia. Musimy stwierdzić, że trafiliśmy dobrze i nie żałujemy swego wyboru. Mało, gdyby dano nam prawo powtórzenia wyboru - studia w Szczecinie, seminarium, praca - to niewiele byśmy zmienili (może porę zakrętów pokonali byśmy nieco inaczej, łagodniej), ale generalnie nie ma co poprawiać.

Dlatego dzisiaj przede wszystkim chcemy podziękować naszym mistrzom - szczególnie Profesorowi Franciszkowi Gronowskiemu i Tadeuszowi Wierzbickiemu, a poza tym chcielibyśmy poczynić parę uwag, które powinny się przydać naszym następcom.

Próba zdefiniowania warunków wyjściowych do odniesionych sukcesów, szczególnie dla regionów peryferyjnych.

Analizując regiony, które znacząco się rozwinęły można stwierdzić, że sukces uwarunkowany jest:

1. Istnieniem realnych sił lokalnych (politycznych, społecznych i samorządowych) zdolnych do poszukiwania kreatywnych pomysłów biznesowych, które możliwe są (były) do zrealizowania w konkretnych uwarunkowaniach gospodarczo-społeczno-politycznych.

2. Wykształceniem (kultywowaniem) modelu - etosu pracy i konstruktywnych zachowań społecznych.

3. Dążeniem do wypracowania nowej struktury produkcyjno-funkcjonalnej regionu. Uwzględnienie zmian społecznych zachodzących w świecie.

4. Skoordynowanym i skutecznym lobbingiem na poziomie centralnym.

5. Uznaniem, że racjonalne działania są tylko te, które nastawione są na korzyść własną, biorąc pod uwagę docierające informacje.

6. Wykształconą kadrą, która stale chce i może doskonalić swoje umiejętności i która szuka zaspokojenia swych dążeń w regionie.

7. Umiejętnym wykorzystaniem inżynierii finansowej.

8. Posiadaniem kapitału.

Należy także podkreślić, że kolejność tych czynników nie ma charakteru przypadkowego a ich gradacja i kolejność są ściśle określone. Dodatkowo jeszcze niezmiernie ważnym warunkiem odniesienia sukcesu jest wykształcenie etosu pracy i dążenie do sukcesu - a to jedna z najsłabszych stron naszego społeczeństwa nie tylko w regionie, ale i w kraju. Imponuje nam wprawdzie wpojona najpierw Japończykom, a później przejęta w Stanach Zjednoczonych zasada, że „praca jest ważna, że pracą można wiele osiągnąć, że właściwie można nią stworzyć wszystko". Próbuje się nam jednak pracę i jej efekty zastąpić historią, powstaniami (szczególnie tymi, które zakończyły się fiaskiem), oby nie powiedzieć, że klęski są fundamentem budowania dumy narodowej Polaków, podczas gdy tak naprawdę jako społeczeństwo mamy olbrzymie sukcesy w np. likwidacji analfabetyzmu, wykształcenia nowej kadry, samodzielnego odbudowania kraju, budowy tysięcy zakładów, dróg, mostów - wszystko własnymi środkami i własnymi siłami. To winno być tym wzorcem przekazywanym, na którym kształtować należy wychowanie następnych pokoleń. Mamy pełne prawo i podstawy do tego, aby pokazywać, że to nasi dziadkowie i rodzice swoją ciężką pracą i swymi wyrzeczeniami podnieśli Polskę ze zgliszcz 
wojennych i zbudowali nowoczesne państwo polskie. Sami zaś pełne zaangażowanie w pracę wykazujemy dopiero, gdy pracujemy za granicą i jakoś nie dostrzegamy tych wzorców na co dzień.

My w zasadzie pomijamy znaczenie zaangażowania, skupiając się na tym, że praca jest ważna, bo daje nam podstawy do utrzymania. W regionie naszym stało się to szczególnie widoczne po upadku Stoczni Szczecińskiej, kiedy to z dnia na dzień okazało się, że sztandarowy zakład regionu może przestać istnieć i funkcjonować, że wiele tysięcy ludzi może stracić pracę, a kilkadziesiąt tysięcy, jeżeli policzymy rodziny, środki do życia. Dlatego klasyczne zasady thatcheryzmu i reganizmu nie znajdują już akceptacji w naszym społeczeństwie, jak i znacznej części społeczeństw na świecie ${ }^{1}$. Pojawiają się nowe podejścia i rozwiązania, które starają się wykorzystywać aktywną rolę państwa i ochronę najsłabszych grup społecznych (sięgając do klasyki: T. Peterson, R.H. Waterman, W poszukiwaniu doskonałości. Lekcje z najlepiej prowadzonych przedsiębiorstw amerykańskich. B. Wawrzyniak, Koncentracja w gospodarce jako światowa tendencja. Grupy kapitałowe w Polsce, Difin, Warszawa 1998). W propagowaniu tych podejść brakuje u nas siły medialnej, mimo że coraz silniejsze staje się przekonanie, iż prywatny pracodawca nie zapewni poczucia sprawiedliwości społecznej, a rozwój i budowa nowoczesnego społeczeństwa nie jest możliwa bez aktywnej roli państwa.

Pomijanie tych zjawisk prowadzi do wzrostu frustracji społecznej i poszukiwaniu różnych dróg zabezpieczeń społecznych oraz coraz większej akceptacji ruchów populistycznych (C. Hampden-Turner, A. Tropenaars, Siedem kultur kapitalizmu, Dom Wydawniczy ABC, Warszawa 1998). Ostatnim tego przykładem jest Brexit czy wybory w Austrii, Hiszpanii, Włoszech lub Francji. My jako społeczność lokalna winniśmy być Europejczykami (stajemy się nimi coraz bardziej), ale nie zapominajmy, że wszyscy Europejczycy są lokalnymi patriotami (a może nawet lokalnymi nacjonalistami, jak np. Walończycy, Francuzi czy Irlandczycy), na których sukcesach tak chcemy się wzorować. Dlatego należy uznać, że wszelakie przedsięwzięcia na rzecz regionu, które zachowują i kreują miejsca pracy, a dodatkowo jeszcze przyczyniają się do powstania nowych podmiotów gospodarczych, które płacą podatki w regionie, winny być traktowane priorytetowo i mieć dostęp do „dźwigni regionalnej”, czyli wszystkich udogodnień jakie mogą zaoferować władze miejskie i regionalne. Udogodnienia te powinny być skierowane przede wszystkim do firm lokalnych (rodzimego kapitału). Należy też pamiętać, że racjonalny jest ten, kto działa na własną korzyść, biorąc pod uwagę docierające do niego informacje, nawet jeżeli informacje te są często zmanipulowane przez osoby, które przez takie działania chcą osiągnąć swoje doraźnie korzyści.

$\mathrm{Na}$ dążenie do równego traktowania podmiotów krajowych i zagranicznych czekamy od dawna. Piętnaście lat temu pisaliśmy:

mamy zupełnie niezłą Ustawę o portach i przystaniach morskich, która stwarza bezpośrednie przesłanki i wyznacza ramy dla działalności portów, daje przesłanki do zmiany struktury portu i jego przekształcenia, w sposób jednoznaczny rozwiązała ona problem, co do sposobu prywatyzacji, dróg prowadzenia uwłaszczenia pracowników, czy też podziału czynności między spółki operatorskie i Zarząd Portu. Dlatego koniecznym wydaje się określenie warunków, na jakich wkraczają porty Szczecina i Świnoujścia w nową, europejską rzeczywistość.

1 O czym świadczą sukcesy partii populistycznych i narodowych w całej Europie. 
Dzisiaj, kiedy jesteśmy mądrzejsi o doświadczenia z tych lat, które minęły, stwierdzamy, że słuszne było zdecydowanie się na rozpoczęcie procesu prywatyzacji portu Szczecin-Świnoujście, której praprzyczyną była prozaiczna chęć ominięcia podatku, wówczas nazywanego popiwkiem. Ta próba uniknięcia płacenia podatku od ponadnormatywnych wynagrodzeń (tzw. popiwku) rozpoczęła na początku lat 90 . XX wieku strukturalną przebudową form własności oraz sposobu funkcjonowania portów w Polsce, w tym w Szczecinie i Świnoujściu. Wówczas to powołano 11 spółek prawa handlowego, które z mocy prawa były od niego zwolnione. Od strony kapitałowej w spółkach większościowymi udziałowcami była załoga i we wszystkich prawie spółkach dominował układ: 55\% udziałów objęła załoga, a 45\% ZPSiŚ SA. Spółki te na zasadzie porozumienia (praktycznie było to następstwo prawne), zatrudniły całą załogę, jaka zaangażowana była w dany typ działalności oraz wydzierżawiły cały majątek, jaki był wykorzystywany w dotychczasowych procesach produkcyjnych. Dokonane przekształcenie, które miało teoretycznie pozwolić jedynie na obejście przepisów podatkowych i ułatwić funkcjonowanie w nowych warunkach, doprowadziło do zupełnie nowej sytuacji gospodarczej w portach polskich.

Szybko okazało się, że samodzielne podmioty gospodarcze są bardzo dobrym rozwiązaniem, pozwalającym przejść na wyższy poziom gospodarowania. Narażone są jednak na ryzyko upadłości czy bankructwa. Przede wszystkim okazało się, że ograniczona jest możliwość bezpośredniej interwencji ZPSiŚ SA (pośredniego lub bezpośredniego wspierania spółek) i występuje koniecznością samodzielnego płacenia przez spółki za popełnione błędy. Chodzi przede wszystkim o błędy popełnione przez zarządy spółek, które były często nieprzygotowane do funkcjonowania w warunkach gospodarki rynkowej. Wystąpiły również negatywne konsekwencje zbyt optymistycznego podejścia przyjętego na etapie tworzenia spółek eksploatacyjnych $^{2}$.

Nastąpił też rozdźwięk między oczekiwaniami społecznymi (załóg poszczególnych spółek) a realiami gospodarczymi. Okazało się, że do nowej sytuacji (nowej roli) nie jest przygotowana „spółka matka - ZMPSiŚ SA”, która chciała rządzić spółkami (w sposób pośredni i bezpośredni) bez ponoszenia konsekwencji za swoje decyzje. Nie przygotowano też długofalowej strategii przekształceń i nie dostrzeżono, że warunkiem powodzenia tych zmian, było budowania własnego majątku i potencjału gospodarczego przez poszczególne spółki eksploatacyjne. Nie stworzono też systemu przepływu informacji (dwustronnego), który by był pasem transmisyjnym przekazywania sygnałów od Zarządu MPSiŚ SA do spółek i sygnałów od spółek do zarządu i Rady Nadzorczej ZMPSiŚ SA. Dodatkowo zaś przyjęto za dogmat, że Zarządu MPSiŚ SA oraz kolejnych rad nadzorczych nie interesuje jak funkcjonują i jakie problemy mają podmioty eksploatacyjne.

W procesach własnościowych dalsze przekształcenia wymusiła pogarszająca się sytuacja ekonomiczna, co doprowadziło do konieczności konsolidacji części spółek oraz sprzedaży udziałów przypadkowym inwestorom. Scalenie okazało się rozwiązaniem bardzo efektywnym, powstrzymało falę nadchodzących nieuchronnie upadłości i zaoszczędziło wielu dramatów osobistych pracowników (co w kilkanaście lat później nie ominęło wielu zakładów w Szczecinie i na Pomorzy Zachodnim).

2 Dużym złagodzeniem napięć i błędów startowych była wyjątkowo dobra koniunktura w porcie, która nie została jednak właściwie wykorzystana do stworzenia należytej bazy majątkowej spółek, ponieważ całość nadwyżek, w formie specjalnych, dodatkowych opłat - np. tonażowej zostały przejęte przez ZMPSiŚ SA. 
Taki sposób przeprowadzania przekształceń własnościowych w portach odbił się negatywnie na mentalności społecznej. Praktycznie bowiem załogę portu ominęły wszelakie zawirowania i niepokoje związane $\mathrm{z}$ utratą pracy, którą przeżywali zatrudnieni w wielu innych firmach w Szczecinie i całym kraju. Wykształcił się nawet taki typ zachowań i stwierdzeń, że port nie poddaje się procesom gospodarki rynkowej i regułom, które można zaobserwować $\mathrm{w}$ innych działach gospodarki. Uzasadniano to tym, że porty współpracowały z gospodarką kapitalistyczną (rynkową) prawie „od zawsze” i dlatego nie muszą przeprowadzać procesów dostosowawczych i restrukturyzacyjnych, bo je już wcześniej uwzględniły. Takie stwierdzenia i zachowania nie były uzasadnione, a wynikały jedynie z owczesnej dobrej koniunktury makroekonomicznej i wzrostu przeładunków portowych. Niewiele jednak zrobiono w tym kierunku, aby w sposób systemowy i obiektywny przygotować port do nadchodzących wyzwań XXI wieku, a szczególnie funkcjonowania w ramach struktur europejskich (co dokonywano wówczas w portach niemieckich i holenderskich, z którymi obecnie musimy konkurować).

Problem ten został dodatkowo pogłębiony przez dobór inwestorów zewnętrznych, którzy mieli uzdrowić i usprawnić funkcjonowanie spółek eksploatacyjnych. Dobór ten okazał się nieracjonalny (przypadkowy i często miał charakter spekulacyjny i doraźny). Nieprawidłowy dobór inwestorów doprowadził do tego, że praktycznie w polskich portach funkcjonuje tylko jeden podmiot, w którym pakiet kontrolny ma podmiot polski. Pominięto w tym doborze, że porty w swym rozwoju muszą uwzględniać triadę - równomiernego rozłożenia uwagi na gospodarkę, czynnik społeczny i ekologię. Preferowanie jednego z tych elementów lub przejściowa koncentracja na jednym z nich (szczególnie ekonomicznego) doprowadziło do nienadążania za postępem, który dyktuje świat. Jest to widoczne szczególnie obecnie w nowo przedkładanej regulacji Unii Europejskiej, która po raz trzeci próbuje uregulować z poziomu Brukseli, jak ma funkcjonować 319 portów w Europie w zakresie dostępu do rynku usług portowych i przejrzystości finansowej portów. Najnowsza inicjatywa, po nieudanych poprzednio dwóch próbach „zorganizowania po nowemu” działalności portowej, charakteryzuje się „miękkim” podejściem i skupia się na stworzeniu zasad dotyczących przejrzystości publicznego finansowania portów oraz opłat dla użytkowników portów. Reforma ma na celu eliminację nieuczciwej konkurencji, zapewniając równe warunki rozwoju portów (pomija jednak to, że przez poprzednie lata porty Europy Zachodniej zostały dofinansowane dużymi środkami z budżetów lokalnych i środków Unii Europejskiej). Jest to kolejna próba jednolitego uregulowania w 23 państwach członkowskich gospodarki portowej, dającej zatrudnienie bezpośrednie lub pośrednie ponad $3 \mathrm{mln}$ obywateli, przez które się przeładowuje około $400 \mathrm{mln}$ pasażerów i 3,7 mld t ładunków ${ }^{3}$. Uregulowania sektora gospodarki, co umożliwia tranzyt około 74\% importu i eksportu i $37 \%$ handlu UE.

Nowe rozporządzenie ma stosować się do portów wchodzących w skład TEN-T, ale państwa członkowskie mogą rozszerzyć jego zastosowanie do innych portów. Nowe przepisy mając na celu zapewnienie przejrzystości finansowej ośmiu typów usług portowych oraz otwarty dostęp rynku do sześciu z nich4. W uchwalonym projekcie zakłada się, że władze portu będą miały autonomię w ustalaniu opłat za infrastrukturę portu, pod warunkiem, że odbywa się to w sposób

3 http://www.liberadzki.pl/index.php?option=com_content\&view=article\&id=1145\%3Arozporzdzenie-portowe\&catid=21\%3Akomisja-transportu-i-turystyki\&Itemid=43\&lang=pl.

$4 \mathrm{Z}$ tych regulacji mają być wyłączone usługi przeładunkowe i pasażerskie. 
przejrzysty. Komisja jednak ma możliwość ustalenia wspólnych zasad pobierania opłat za pomocą aktów delegowanych. Proponowane Rozporządzenie ma też na celu zwiększenie przejrzystości w wykorzystywaniu środków publicznych. Władze portowe nie będą zobowiązane do publikowania szczegółowych rozliczeń, ale będą musiały dostarczyć te informacje do krajowych i unijnych organów nadzoru. W warunkach Polski próba ograniczenia i w miarę sztywnej regulacji finansowania ze środków publicznych doprowadzi do zahamowania rozwoju wielu z nich. Większość portów Europy Zachodniej przez lata otrzymywała znaczną pomoc od swoich rządów, co przełożyło się na ich znaczny rozwój i rosnącą dysproporcję pomiędzy portami w Europie zachodniej i wschodniej. Polskie porty ciągle potrzebują dużych inwestycji infrastrukturalnych i wsparcia, aby móc skutecznie konkurować z dużymi portami Europy Zachodniej. Dlatego uważamy, że rozporządzenia może skutkować osłabieniem polskich portów i utrudni to przygotowanie się do konkurowania z portami Europy Zachodniej. Jest próba łagodnego zablokowania zmian strukturalnych w portach polskich.

Chcąc złagodzić nieco skutki tych postanowień, przewiduje się w poszczególnych krajach Unii Europejskiej możliwość wprowadzenia okresów przejściowych dla firm eksploatacyjnych, które dokonały inwestycji w suprastrukturę - przyjmując, że okres ten w zależności od wielkości nakładów może wynosić 5/10/25 lat, a dla firm inwestujących w infrastrukturę 10/15/36 lat. Przy czym jeszcze dodatkowo w obu przypadkach przewiduje się możliwość 10 letniego okresu przedłużenia zawartej umowy pierwotnej. Te i inne zabezpieczenia są wprowadzane obecnie pod presją związków zawodowych (szczególnie tych z krajów Europy Zachodniej), ale faktycznie podyktowane są z dążeniem do zachowania racjonalnego poziomu technicznego działania portów. Dotyczy to nie tylko portów polskich, ale i większości portów niemieckich i holenderskich.

Jeżeli zaś w naszych portach nic nie zostanie zrobione w kierunku zawarcia długoletnich umów dzierżawy, to na zasadzie najsłabszego ogniwa w całym systemie gospodarki portowej Europy, cała presja na zmiany zostanie zwrócona w kierunku portów polskich, które mają te kwestie nieuregulowane, czyli w szczególności Szczecina i Świnoujścia.

Poczynione uwagi pokazują, że działalność portowa znajduje się obecnie w punkcie zwrotnym i jeżeli nie zostaną podjęte kroki przygotowawczo-zapobiegawcze, to praktycznie działalność portowa dotychczasowych podmiotów gospodarczych może zostać w stosunkowo prosty i legalny ograniczona lub nawet wyeliminowana. Niezbędne wydaje się więc przebudowanie istniejącej strategii działania i przygotowanie zmian w sposobie funkcjonowania i zasadach współpracy zarówno w odniesieniu do Zarządu MPSiŚ SA, jak i spółek eksploatacyjnych, tak aby dostosować się do nowej sytuacji prawnej i organizacyjnej.

Jako zadanie priorytetowe w dalszej działalności należy uznać takie cele jak:

1. Remont i modernizacja nabrzeży w porcie szczecińskim oraz dostosowanie techniki przeładowczej (placów składowych, dźwigów i magazynów) do technologii i rat przeładunkowych wykonywanych w portach Europy Zachodniej.

2. Zmiana przez ZMPSi Ś SA polityki stawek dzierżawnych, z drenażowych opłat dzierżawnych, na konstrukcję stawek stymulujących wzrost masy przeładowywanej, stymulującej nowe inwestycje i nowoczesne organizacje przeładunku, co będzie prowadzić do wzrostu poziomu efektywności spółek eksploatacyjnych i tym samym wzrostu efektywności funkcjonowania całego organizmu portowego. 
3. Utworzenie centrum logistycznego, co spowoduje, że do portu zacznie płynąć nowa masa ładunkowa.

4. Rozpoczęcie działalności makromarketingu, co pozwoli na pozyskanie nowych i ewentualne odzyskanie utraconych dla portów strumieni ładunków.

5. Wypracowanie wspólnego zaplecza sztauerskiego, które obsługiwać będzie wszystkie spółki eksploatacyjne. 